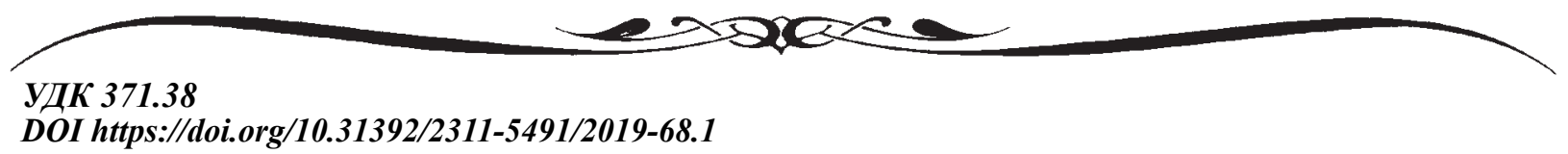

Atakişiyev Elvin Mübariz ŏglu

\title{
INNOVATIONS IN CURRICULUM
}

The article notes that since schools exist, planned innovations or reforms are used as a tool to destroy traditional school experiences and, thus, are designed to adapt to changing living conditions. Curriculum perspectives for the implementation of planned innovations are the best example. These implementation measures are not always successful, they are the usual counterbalance to the experiments in this area. Experience shows that if reforms provide a chance, many components will appear objectively. For example, defining only new materials or curricula is insufficient. Other methodologies, other organizational aspects and didactic key ideas should also be included.

It is noted that other aspects of this process are how to clarify and formulate the objectives of the curriculum, reflect the advantages and prerequisites and describe it from the perspective of teachers. In this regard, the content and practical design of the curriculum greatly helps teachers to accelerate students' understanding of specific instructions and examples and eliminate their anxiety.

Innovation is most effective and achievable when involved in the process of developing thinking and personal influence with participation. Various activities, including intermediate sessions, school conferences, online surveys, should be strengthened and shared during general development. The purpose of these activities is to train teachers in overcoming the effect of primacy, providing them with the necessary information about the current state of development and integrating them into the process of general educational development.

It is also noted that an equally balanced system of training can interfere with the positive effects of external factors and the solution of intra-organizational problems. Weakening change processes lead to dissatisfaction with the school students'learning, and certain situations or events are no longer considered tolerable or helpful. These mental states or their consequences (for example, failure of students, lack of education, parental care) can lead to changes in the educational process.

Dynamic development should be so intense that other teachers should be involved in the innovative learning process, as they can innovate in their personal experience. At the same time, the school administration must support proactive staff on a mandatory basis.

Finally, there are some difficulties that arise as a result of the didactic thinking of teachers, while self-justified habits are influenced and strongly influenced, and gradually change. In view of all this, it can be concluded that innovations are assigned to longterm time horizons, developed with long-term tolerance, considerable support, inspiration and examples of new didactic thinking.

Key words: innovation, school, educational institution, education plan, teachers, innovative projects.

(статтю подано мовою орихіналу)

Since the existence of schools, planned innovations or reforms are used as a tool for breaking the school experience, and are thus intended to take into account changing living conditions. Curriculum plans for implementation of planned innovation are the best example. These implementation measures are not always successful, they are just the balance of experiences in this area. Fyla has shown that if reforms are given a chance, many things need to emerge together. For example, if only new materials or curricula are assigned, this is not enough. Other methodologies, other organizational dimensions, and didactic key ideas should be included in this. Actually, innovation takes place in a very long way. However, when viewed by the body, the mix of scientific intelligence and the content of specific curriculum content is a long process.

Mine goal article. To consider some of the positive details of innovative curricula most widely used in the educational process in the modern period. Show that to use the curriculum successfully, you need not only the smallest details, but also an underscore of the main goal and wide areas of coverage of the topic.

Earlier in the early 1990s, some of the lesson plans were out of date.

"In addition to organizational development, the lesson is the true cause of education, upbringing and education, yet the goal is to further improve the school's development, namely the rise of school achievements and qualities" (Schrats 1995, 269).

Previous studies have already revealed that innovations in the lesson plan are conditional on lessons.

It has become clear that the innovations in the school's daily life can never be a major coup because the existing norms and practices are endangered and this leads to a harsh criticism of what has been so far. In any case, the content of the clear edged innovation should be known, and it can separate only one part responsible for it. Most school pedagogical reforms are very ideal and innovation that promotes optimal projects frustrate teachers and therefore have a terrifying and motivating impact.

Another aspect is how to clarify and formulate the curriculum objectives, reflect the benefits and background, and describe it in terms of teachers. This is a very positive impact when it comes to lightening and freezing for teachers. In this regard, the content and practical layout of the curriculum are very helpful in accelerating the meaning of specific guidelines and examples and eliminating fear. Also, limitation of one-on-one requirements may, on the one hand, eliminate suggestions and suggestions on the one hand and, on the other hand, eliminate misunderstandings and uncertainties.

However, the curriculum should clarify for its own formation: Guidance lines and curricula are most appropriate at the time, not just the smallest dimensions for it, but also the main objectives and broad areas of the theme that are 
clearly outlined. Not only the abundance of material but also the pressure on the instructor is restricted to them, and the feeling of confidence in their work is usually limited, and in general they should be given the opportunity and conditions to go to their own creative and relevant pupils.

Innovations are the most effective and achievable when the understanding of the development process and the personal impact of participation are involved. Various activities, including sessions, point-of-view, intra-school conferences and improvements, internet surveys should be intensified and exchanged during common development. The purpose of these events is to educate teachers in the first time of the renewal period, to provide information about the current state of development and integrate them into the development process.

If the relevant subjects are "transported" and, to be more apparent, there is more chance of renewal in daily school life.

If he believes that teachers are taken seriously and confidence grows, then the subject is replaced by both, and both conditions make it easier for adopting pedagogical and other innovations and finally identifying them. Innovative projects in the curriculum remain unclear and incomprehensible unless they are professionally crafted, codified, or operated. They are also featured in a specially-expanded work project. Here you also need to refer to the impulses referring to the subjects, and then show the next development path, which is important step by step. At the same time, pedagogical innovation requires a time-lapse of chance; Heinz has distinguished a few moments: the most difficult moments of innovation and the favorable moments of adopting new pedagogical ideas, such as the fact that schools are already thinking about their respective directions.

Holtappels speaks of the "paradigm that refers to the weight" in relation to the "correct time" change.

An equally weighted system of a school can interfere with external factors and internal organizational problems. Crashing for change results in dissatisfaction with the work of school members, and certain situations or events are no longer considered as tolerable or useful. These mental states or their impacts (eg, students' failure, stupidity, depressed parental support) can lead to a change in demand, which can lead to "equal weight (ie the quality of the school that has agreed). From the overlapping analysis of factors that hinder the innovation process, we can talk about the development of a new direction in the re-creation of weight" (Holtappels 1995, p. 38).

\section{School structure and innovations}

Innovations are a crucial step to encourage, advance, and support accelerated innovation. The pedagogical-organizational, self-renewal capabilities of any school, especially the teaching staff, depend on the innovation potential, the development of school-based identity, and above all, the pedagogical management of the school leadership.

\section{School administration}

One of the important signs of ordinary understanding of organizations is the independence of personality and the relevance of the instructions in the bureaucracy model. Here, service tips lead to succession of innovations; school change is implemented by managing the application, for example: a new key line for a subject. The efficiency of the innovations implemented is justified in rational-practice strategies, hence the reasons for innovation are intelligent and forward-looking.

Management and Rational-Practice Strategies have certain limitations in school innovation, and often they need to be settled by dividing innovations into their own values, motives, and skills, skills, abilities and spatial areas. If school leadership plays a decisive, impetuous role at this time, innovations have only one chance at school. One of these is the fact that innovations are concentrated in psychological support, with confidence and sincerity of teachers by the encouragement, admonition and respect of the school leadership. On the other hand, it is important to understand that managers, as well as ideas, impulses, and also accelerate the development of the demand, should pay attention to the development of these innovations through the board. It is of paramount importance to adopt and develop the collective powers and their acceptance by the colleagues and their own personal experiences. Dynamic development at this time should be so intense that other teachers should also involve themselves in attending, because they can innovate in their personal experience. At the same time, there is a commitment to the school administration to support the recruiting and recruiting staff who are looking for new initiatives.

The most consistent goal of management is to create a comprehensive learning culture at school. This allows the instructors to make new experiments, to live up to the new perspectives in the lesson, to get acquainted with alternative methods, and thus achieve consistent and best understanding of innovation. Nevertheless, the establishment of a complex school-based infrastructure for co-operation and communication is a prerequisite, which accelerates problem-solving. Not just the way of co-operation and learning of the culture of learning, it is often necessary to lay the foundations of information in many cases. The so-called conditions are based on the development of general positive innovation climate by the school and its leadership (school-based mobilization, communication and co-operation), and the spread of innovations in school is largely dependent on school morale, norms and culture in the board, and spirit of the organization. If you are talking about "Errors in the culture", tolerance in the board plays a crucial role and allows them to talk about personal problems without damaging their authority.

\section{Parents}

Finally, in this acquired innovation process, parents also have their own share. Only then can it be that if parents and children under the supervision of the school are informed about innovation, they should go forward with frequent work with their parents. The main purpose of all of these activities is that you need to better communicate school work to parents, to facilitate a pedagogical dialogue, and to strengthen the impact of parental involvement in their school work. 


\section{Innovations and teachers}

The curriculum depends on the role that teachers in the learning process play in the overall implementation process. The new pedagogical lesson is being developed by newer skills development and new experiences in the learning process of time intensity. The goal here is to alter the placement of examples of substantive operations that have been practiced so far. Traditional training for changes often has problems. To make the innovations more effective in the school life, it is essential that teachers have sufficient time to study, such as training and testing in everyday practice, and that will give them a sense of freshness. If these factors are taken into consideration, it is advisable to spread the experience to teachers. If all this happens with the help of colleagues, it is very important because the information obtained by the board is as important as communication in the same situation.

Conclusions. Even if the aforementioned favorable conditions are met, the condition of innovations in general is not so easy in such schools. Heinh said: There are many progressive, but some of the weakening effects of stable development. For example, such innovative developments are under pressure, and maybe even an inattention causes mistakes. If closer parts of the school system are increasingly important, traditional basic pedagogical ideas are important. Cuttings in the source of the assistive means also slow down the development and limit motivation. Finally, there are some difficulties that arise as a result of the didactic thinking of teachers, while self-justifiable habits are exposed and strongly influenced and gradually change. In view of all this, it can be concluded that innovations are assigned to long-term time horizons, being developed with long-term tolerance, considerable support and tolerance, inspiration and examples of new didactic thinking. These conditions are now being channeled to the development of a positive climate of innovation by the school and its leadership, and the spread of innovations in school is largely dependent on the school morale, the norms and culture of the board, and the spirit of the organization.

\section{References:}

1. ISB(2005 a): Glossar. Begriffe im Kontext von Lehrplänen und Bildungsstardats, S. 30.

2. Die Anforderungsszufen für die Zielklasse Wisse waren.

3. Tillmann K. J. Lehrpläne und alltägliches Handeln von Lehrer, 1997.

4. Schlegel P. S. Zur Situation der empirischen Lehrplanforschung, 2003. S. 41.

5. BMBF, Zur Entwicklung nationaler Bidungsstandards, 2003. S. 36.

6. Der Lehrplan der ehemaligen DDR, Vollstädt, 1995. S. 17-42.

7. Heinisch T. Bedingungen für eine erfolgreiche Umsetzung curricularer Innovationen in der Schule, 1994. S. 10.

\section{Атакішіев Ельвін Мюбаріз огли. Інновації в навчальній програмі.}

Наголошується, щуо оскільки школи існують, заплановані інновації або реформи використовуються як інструмент для руйнування традииійного шкільного досвіду $і$, таким чином, призначені для адаптації в мінливих умовах життя. Перспективи навчальних планів для реалізащії запланованих інновацій є найкращцим прикладом. Ці заходи з реалізації не завжди успішні, вони є звичайною противагою дослідів у иій галузі. Досвід показує, шчо якщо реформам надати шанс, то багато складових компонентів з 'являться об'єктивно. Наприклад, визначення тільки нових матеріалів або навчальних планів є недостатнім. Сюди мають бути включені також інші методологї, інші організаційні аспекти та дидактичні ключові ідеї.

Зазначається, щчо інші аспекти в цุьому процесі полягають в уточненні та формулюванні цілей навчальної програми, відтворенні переваг $і$ передумов, а також описі з позииії вчителів. $У$ зв'язку із ичим зміст і практичне оформлення навчального плану дуже допомагає вчителям прискорити осмислення учнями конкретних вказівок $і$ прикладів та усунути їх тривожність.

Інновачії є найбільш ефективними й досяжними, коли учні залучені в прочес розроблення розуміння. Різні види діяльності, у тому числі проміжні сесії, внутрішньошкільні конференції, інтернет-опитування, повинні бути посилені та проводитися в ході загального розвитку. Метою ичих заходів є навчання вчителів подолання ефекту первинності, надання їм необхідної інформації про поточний стан розвитку та інтеграція їх у процес загального освітнього розвитку.

Так само зазначається, щзо однаковою мірою збалансована система навчання може заважати позитивним впливам зовнішніх факторів і вирішенню внутрішньоорганізаційних проблем. Ослаблення проиесів зміни призводить до незадоволеності навчанням учнів школи, і певні ситуації або подї більше не вважаються терпимими або корисними. Ці психічні стани або їх наслідки (наприклад, невдача учнів, ненавчених, батьківська опіка) можуть привести до зміни освітнього проиесу.

Динамічний розвиток має бути настільки інтенсивним, що й інші вчителі мають бути залучені в інноваційний прочес навчання, бо вони можуть вводити нововведення в свій особистий досвід. Водночас адміністрація школи має надавати підтримку ініціативному персоналу в обов'язковому порядку.

Зрештою, є деякі труднощі, які виникають у результаті дидактичного мислення вчителів, у той час як самовиправдані звички піддаються сильному впливу і поступово змінюються. Зважаючи на все ие, можна зробити висновок, щуо інноваџї̈ присвоюються довгостроковим часовим горизонтам, які розробляються з довгостроковою терпимістю, значною підтримкою, натхненням і прикладами нового дидактичного мислення.

Ключові слова: інновачія, школа, навчальний заклад, навчальний план, вчителі, інноваційні проекти.

Атакищиев Эльвин Мюбариз оглы. Инновации в учебной программе.

Отмечается, что поскольку школь существуют, запланированные инновации или реформы используются в качестве инструмента для разрушения традичионного школьного опыта и, таким образом, предназначены для адаптации в меняюшихся условиях жизни. Перспективы учебных планов для реализации запланированных инноваций являются 
лучшим примером. Эти меры по реализации не всегда успешны, они являются обычным противовесом опытов в этой области. Опыт показывает, что если реформам предоставить шанс, то многие составляющие компоненты появятся объективно. Например, определение только новых материалов или учебных планов является недостаточным. Сюда должны быть включены также другие методологии, другие организачионные аспекты и дидактические ключевые идеи.

Отмечается, что другие аспекты в этом процессе заключаются в том, как уточнить и сформулировать цели учебной программы, отразить преимущества и предпосылки и описать ее с позиции учителей. В связи с этим содержание и практическое оформление учебного плана очень помогают учителям ускорить осмысления учащимся конкретных указаний и примеров и устранить их тревожность.

Инновачии являются наиболее эффективными и достижимыми, когда учащиеся вовлечены в процесс разработки осмысления. Различные виды деятельности, в том числе промежуточные сессии, внутришкольные конференции, интернет-опросы, должны быть усилены и проводиться в ходе общего развития. Целью этих мероприятий является обучение учителей преодолению эффекта первичности, предоставление им необходимой информации о текущем состоянии развития и интеграџия их в процесс общего образовательного развития.

Также отмечается, что в равной степени сбалансированная система обучения может мешать положительным воздействиям внешних факторов и решению внутриорганизационных проблем. Ослабление процессов изменения приводит к неудовлетворенности учебой учеников школь, и определенные ситуачии или события больше не считаются терпимыми или полезными. Эти психические состояния или их последствия (например, неудача учащихся, необученных, родительская опека) могут привести к изменению образовательного процесса.

Динамическое развитие должно быть настолько интенсивным, что и другие учителя должны быть вовлечены 6 инновационный процесс обучения, так как они могут вводить новщества в свой личный опыт. В то же время администрачия школь должна оказывать поддержку инициативному персоналу в обязательном порядке.

Наконец, есть некоторые трудности, которые возникают в результате дидактического мышления учителей, в то время как самооправданные привычки подвергаются воздействию и сильному влиянию и постепенно изменяются. Ввиду всего этого можно сделать вывод, что инновации присваиваются долгосрочным временным горизонтам, разрабатываемым с долгосрочной терпимостью, значительной поддержкой, вдохновением и примерами нового дидактического мышления.

Ключевые слова: инновация, икола, учебное заведение, учебный план, учителя, инновационные проекты.

УДК 373.3.091.64:305 (045)

DOI https://doi.org/10.31392/2311-5491/2019-68.2

Байдюк Н. В., Здір Д. Р.

\section{ГЕНДЕРНИЙ АНАЛІЗ ПІДРУЧНИКІВ ДЛЯ ПЕРШОГО КЛАСУ З ІНТЕГРОВАНОГО КУРСУ “Я ДОСЛІДЖУЮ СВІТ”}

Розкрито методику та результати гендерного аналізу підручників для першого класу з інтегрованого курсу “Я досліджую світ”. У процесі аналізу враховано: кількісну диспропориію представлення осіб обох статей, зображення чоловіків /жінок переважно в стереотипних гендерних ролях, сегрегацію і поляризацію за ознакою статі, передачу загальнолюдських иінностей виключно через образ чоловіка, використання гендерно чутливої мови, наявність/ відсутність сексизму. Здійснений аналіз дав можливість встановити у досліджуваних підручниках наявність гендерних стереотипів, щзо мають негативний вплив на соиіалізацію дітей, їх професійну та особистісну самореалізацію в майбутньому. Основними рекомендаціями щодо покращення змісту підручників є: усунення диспропориії представленості обох статей, зміна стереотипних зображень нестереотипними, приділення повноцінної уваги ролі жінок у суспільному житті.

Ключові слова: антидискримінаційна експертиза підручників, гендерний аналіз, підручники для початкової школи, гендерна дискримінаиія, гендерна соџฺіалізаџія, гендерний стереотип.

Згідно з Державним стандартом початкової освіти, серед ключових компетентностей випускника Нової української школи - громадянські та соціальні компетентності, пов'язані з ідеями демократії, справедливості, рівності, прав людини. Тому серед важливих завдань реформування системи освіти - виховати особистість, яка усвідомлює рівні права і можливості, поважає індивідуальні особливості інших осіб, уміє діяти в конфліктних ситуаціях, пов'язаних із різними проявами дискримінації.

3 метою відповідності підручників для 1 класу чинному законодавству та недопущення проявів дискримінації, Міністерством освіти і науки України запроваджено конкурсний відбір проектів підручників для 1-2 класів закладів загальної середньої освіти (наказ МОН від 02.04.2018 р. № 310). Зокрема, антидискримінаційна експертиза - це аналіз оригінал-макетів підручників стосовно наявності в текстових та позатекстових матеріалах проявів дискримінації за захищеними ознаками (раса, колір шкіри, політичні, релігійні чи інші переконання, стать, вік, інвалідність, етнічне та соціальне походження, мова тощо) у формі стереотипів, ксенофобії, ейджизму, андро- та етноцентризму, сексизму та надання рекомендацій щодо їх усунення. 